\title{
KERKBESEF IN HISTORIESE PERSPEKTIEF
}

\section{Inleiding}

In die opgawe skuil 'n onmoontlikheid. Waar en hoe kry jy „kerkbesef" op 'n skaal om te weeg of om dit onder 'n meterlyn op te meet? Tweedens, in dié opgawe lê 'n kontradiksie. Kerkbesef veronderstel die hede, nou. Historiese perspektief vra na die verlede. Niemand kan regter in sy eie saak wees nie - wie gaan histories uitspraak doen oor die hede - en wie gaan regter wees om die hede te daag met die verlede as norm?

Aan die ander kant ken die gelowige die kontinuïteit, bely hy dat God ook sy wil en dinge aangaande die mens in die groot aktief van die geskiedenis bekend maak. Soos uit God se besondere openbaring (Bybel) kan daar ook in en vir die hede ou en nuwe dinge uit die geskiedenis gehaal word.

Ek gee dus toe dat hierdie onderwerp 'n sekere stellingname vereis. In die historiese wetenskap sal dit subjektief heet en dus nie geskiedenis kan wees nie - eerder 'n meditasie oor en uit geskiedenis.

Popma sê historiese besef is 'n voorwaarde vir ons taakbesef, want ons taak is steeds ' $n$ taak in die geskiedenis. As sodanig is elke jaar betrokke by die vorige en vanjaar betrokke by 1859 , 1517 en Pinkster.

\section{Aanduiding van begrippe}

2.1. Kerkbesef in historiese perspektief het uiteraard met die mens te doen wat leef en dink en daarom 'n ,besef" het of behoort te hê.

2.2. Kerkbesef het primêr te doen met die vraag: hoe dink die gemiddelde mens oor, van en in die kerk? Wat word met kerk bedoel en baie konkreet: wat is sy besef van die "Gereformeerde Kerk” (wat die begrip ook al ,plaaslik”, ,in verband” en ,as verband" en , in die algemeen" bedoel)?

In hierdie vrae staan die sigbare, institusionele, maatskaplikbekende fenomeen waarskynlik voorop en selfs los van die wesenlike, wat die kerk is of moet wees om waarlik kerk te wees. Te maklik lees predikante hulle teologiese konsepsie van wat die kerk behoort te wees in asof lidmate daaronder dieselfde verstaan of die eie kerk so „teologies" regverdig.

2.3. Kerkbesef vra na die houding van die mens teenoor wat hy as kerk ken. Besef het immers te doen met 'n begrip, met verstaan en daarom ook met die sin, die betekenis wat kerk vir dié mens het. Nog meer: „,besef” vra ook na die motivering. Kortom, is die ou mens, gemiddelde mens, jong mens vandag by die ,kerk" betrokke? Het sy mens-wees ook verband met sy kerk-wees en omgekeerd? Is daar enige motivering om betrokke te wees by die kerk-wees vandag? En hoe was dit gister?

2.4. Historiese perspektief veronderstel dus dat ons die visier rig op vandag met die hele pad van geskiedenis terug na 1859 as 
die diepte reliëf - en nog dieper terug na die Reformasie van die sestiende eeu - om uiteindelik tree vir tree terug te gaan en vas te kyk teen die kerk in die N.T.

Ek dink ons stem saam dat die opgawe onmoontlik is. Ons kan nietemin 'n swak pentekening probeer gebruik om die onmoontlike groot werklikheid nader aan ons te bring as ons werklikheid.

\section{Kerkbesef leef in of ontbreek by die mens vandag}

Kerkbesef tree na vore in die unieke houding en motivering van die mens vandag. Baie noem "die" mens "moderne mens" en neem hom op grond van sy eksistensiële werklike teenwoordigheid, op grond van sy eie besondere kenmerke, as norm waarby en by wie aangepas moet word. Die vraag is dan nie of die "moderne" mens kerkbesef het nie - maar die vraag word dan geformuleer: het "die kerk" (wat ook al met ,kerk” bedoel word) „,mensbesef”, veral begrip van die ,moderne mens" en pas die kerk by dié mens aan?

Die vraag na kerkbesef is in hierdie benadering totaal irrelevant. Die mens het immers gerevolueer. Hy is anders. Daarom is die verlede nie ter sake nie. Hy is nie meer 'n ,ou-mens" in die sin van die Skrif of in die sin van tradisie of geskiedenis nie. Hy is 'n ander en 'n nuwe mens, sonder Jesus Christus en sonder en buite enige werk van die Heilige Gees. Hy is die toppunt van evolusie.

W. D. Jonker teken iets van die „moderne” mens in (,,Liturgische Oriëntatie") en sê die tegniek en kommunikasiemiddels het dié mens uit sy lokale leefwêreld geruk en hom wêreldburger gemaak. Hy soek dan (as hy nog soek!) die ekumeniese beweging en religie en hy stoot hom aan enige lokale kerklike gespletenheid. Sy wêreldpolitiek het 'n religieuse wortel (kommunisme en ekumenisme staan bv. teenoor lokale kerk). Hy vra nie na die verhouding mens-God met die implikasies vir die individu en volk (gemeente) ten opsigte van sonde en skuld nie. Hy vra na internasionale relevansie - Hy interesseer hom in die oorlogsvraagstuk, sosiale verandering, opheffing van kolonialisme, rasisme, ongelyke inkomsteverdeling, ens. In die verlede is gevra: Wat beteken Jesus Christus vir my? Die mens vandag vra: Wat beteken Jesus Christus vir die wêreld? Gevolglik is 'n vraag soos: Wat beteken ek vir Jesus Christus? totaal vreemd en 'n vraag: Wat beteken ek vir die kerk? absoluut sinloos. Die mens sê as Jesus en die kerk niks vir die wêreld beteken nie, dan het die mens aan hulle ook niks nie.

Hierdie blote gerigtheid op die mens se eksistensie en sy daarwees laat die mens die ,hoor-gemeente" uitspoeg. Hy soek en vra na 'n „doen-gemeente" - met 'n nuwe eenheid as die ware koinonia rondom die nagmaaltafel. Ware demokrasie (soos „ons" mense dit wil) kom teenoor die kerklike burokrasie (soos hulle dit wil) te staan en by die minste wrywing isoleer die mens hom van die burokrasie.

J. C. Hoekendijk („De Kerk binneste buiten”) sê die kerke fungeer nog in die kultuur-milieu van die ,derde mens" wat produk van die antieke „Christelike beskawing met sy persoonlikheidskul- 
tuur" was. Alle kerklike evangelisasie is 'n soort „,kerklijke kustvaart" waarmee gesoek word na kommunikasie met die ,derde mens". Ondertussen het breë lae van die bevolking, die sg. proletariaat, hulle juis teen hierdie ,derde mens" gekeer. Hulle wil niks meer met die kultuur te doen hê nie en in hulle oë is die ,derde mens" met sy kultuur en kerk 'n ,curieus anachronisme” (p. 56).

Die nuwe benadering dagteken die aankoms van die ,vierde mens". Die vierde mens het volledig geswig vir die tiran: Feit. Hy onderwerp hom volledig aan 'n situasie. Sy profiel is dié van 'n rebellerende konformis. Hy is nie 'n volgeling van iets, 'n -is (soos 'n Calvinis) nie. Hy is nie sommer vir of teen iets nie. Hy poseer as ateïs, maar bly met God twis; hy vertoon die beeld van nihilisme, maar wil jou tegelyk oortuig van waardes wat hy aanhang; hy sing 'n loflied op vryheid, maar hy gaan op sy pad van vryheid sy doem tegemoet... Sy simbool is Sisyphus, die ",held van absurditeit" wat grapmakend voortploeter, al weet hy dat al sy gedoen hom nêrens bring nie. Hy hoop nie meer nie en hy verveel hom te midde van al sy drukdoenery en geskreeu. Hy sing: „Ons masjeer! Ons masjeer!" maar hy staan op een plek en niemand kom vooruit nie. Die ,moderne mens" word 'n apokaliptiese teken: post-christelik; post-kerklik; post-burgerlik; post-persoonlik; met as ope vraag: postreligieus.

Post-Christelik: Christendom word nie meer relevant vir die lewe geag nie - hoewel die mens in grenssituasies van geboorte, huwelik en dood nog 'n Christelike ritueel sal vashou.

Die post-kerklike is baie sterker. Kerk beteken vir die ,vierde mens" net dat daar 'n dominee op 'n preekstoel staan en hy praat. Hy verstaan die man nie. Wat hy nog verstaan, oortuig hom dat die ,dominee'-man min of meer vyandig teenoor hom en sy lewe staan. Die dominee verstaan ook nie die ,vierde mens" nie. Die dominee hou hom op met die ,derde menslike" lewe - waarmee hierdie „vierde mens" juis klaar gebreek het. Die „derde mense” is vir die vierde mens vreemdsoortige mense wat elke Sondag baie formeel aantrek, party selfs tweemaal; dan gaan sit hulle doodstil en leweloos sodat 'n dominee met hulle kan praat en raas of clichés of argaïstiese onverstaanbare preke uitryg; hulle sleep-prewel sulke trekkerige moeë liedere by 'n oordonderende eentonige orrellawaai ... Kortom, die ,derde" mens het 'n sug na uitwendige deftigheid, kinderagtigheid, leweloosheid, saaiheid, sentimentaliteit, neerslagtigheid en Sondag-roetine. Wie „derde" mens is, kan selfs die naweek nie homself wees nie - maar laat hom in met dominee-dienste.

Hoekendijk sê die mens binne en die mens buite die kerk leef in twee wêrelde ,dic elk een monoloog met zich zelf schijnen te voeren". Die kerkbesef van hierdie ,vierde mens" is nie meer anti-klerikaal en anti-kerklik nie - dit is eenvoudig so dat die kerk vir hom prakties nie bestaan nie en dat kerklike doenigheid en aktiwiteit hom nêrens raak of aanspreek nie. Hy het daar niks aan nie. Hy weet dit is daar - soos wat 'n museum daar is. Wie wil kan daarheen gaan, maar ,in een museum val geen levensbeslissingen” (Hoekendijk, p. 63). 
Ampsdraers is vir die vierde mens die beroepskerkmense. Die dominee is of hy daarvan hou of nie die liefhebber van stereotipe formaliteite, 'n handelsreisiger wat plegtighede voorsien. IJy is; "geïncarneerde kerk" en hy gedra hom ook dikwels of hy dit wil wees. Daarom staan hy vreemd en buite die lewe van die mense en hy word beleefd of onbeleefd as buitestaander behandel. Hy is kameraad van die begrafnisondernemer - nie kameraad van die mens in die lewe nie.

Hierdie hele kerkbesef van die sg. „vierde mens" hang dan ook saam met die houding van die mens teenoor sy nasionale- en familieidentiteite. Dié vierde mens is gekweek met filosofie i.p.v. godsdiens; opgevoed sonder geskiedenis-besef, maar met 'n sterk evolusiebesef; sonder Skrif-besef maar met 'n besef van materie; gekweek in die klimaat van Europese Empires wat gestaan het teenoor die veragte „,kultuurlose” kolonies. Die ,vierde" mens stort en verloor sy eertydse Ryksidee en Ryksgrootheid nou met skuldbesef in 'n groter internasionalisme. Daarom verag hierdie ,vierde mens" die burgerlike kategorieë waarin die godsdiens en die kerk hom aangedien het en aandien. Christelike etiek is vir hom niks anders as 'n stuk „burgerlike denke" nie.

'n Mens moet toegee dat op die preekstoel dikwels baie burgerlike propaganda gemaak is. Evangelisasie is dikwels in noue bondgenootskap met die burgerlike kultuurmilieue gedoen. Kleredrag en haarstyl weeg maklik swaar in die kerk en prediking. Sending word dikwels gedoen met die sg. „onvermydelike” element van verwestersing. Kortom, van enige buitestaander selfs die Hollandse immigrant - word verwag dat hy die burgerlike patroon van die Afrikaanse kerklike lewe sal aanneem. M.a.w. hy moet sy Christendom in die idioom van bv. Afrikaans-wees uitleef anders is hy nie aanvaarbaar nie. Sy ,,gereformeerdheid" moet hom die Nasionale Party laat ondersteun. Nonconformisme word nie geduld nie. Hy moet nie in mode, politiek, kultuur afwyk nie. Hy moet ,polities" primêr nieprogressief wees nie. Hy durf die eie en plaaslike Afrikaanse kerkstruktuur nie kritiseer nie. - Indien hy dit doen, is hy onaanneemlik. Indien hy nie „,burgerlik" inpas nie, word hy nie gekies op die kerkraad nie. Hy word na die rand gerangeer. Dit is 'n groter sonde om te sê dat kerksang met 'n ghitaar i.p.v. 'n orrel begelei moet word - as wat dit sou wees om te sê dat die Gereformeerde belydenis archaīsties, imkompleet of selfs foutief is! Wie die orrelbegeleiding of die mode in die kerk aantas, tas die ,deftig. heid" van die erediens, evangelie of kerk aan. , En met de deftio. heid staat of valt de burger" (Hoekendijk, p. 65). So isoleer die burgerlike kerk hom ook van die vierde mens.

Post-persoonlik: Die tema is vandag nie meer dié van clie klassieke en die Renaissance nl. mens of individu nie. Die „ek"-besef het ,verrafel". Die mens is nie meer geïnteresseerd in refleksie of denke oor die „ek" nie. Daar is genoeg afleiding, radio, film, tydskrif, boeke om hierdie denke uit te skakel of te ontloop.

Die ,vierde mens" benader die lewe met 'n kollektiewe ekbegrip, soms die groep wat hy ,ons" noem, bv. ,die jeug van vandag”, 
of „ons jongmense", of die demos, die heroute van die nuwe sosiale en sosialistiese utopia; óf in sy wydste begrip „ons mense". Op religieuse terrein is dit dan ,die Christene van die wêreld"; die evangelie as hoop vir die wêreld; en die vraag wat doen die kerk vir die wêreld? Hoe staan die kerk teenoor die wêreldmening?

In hierdie benadering is die persoonlike beslissing uitgeskakel. 'n Vraag soos: wat is jou enigste troos in lewe en sterwe is totaal irrelevant. Dit is tevergeefs en verkeerd om te roep: kies wie jy wil dien, of waar jy wil wees, omdat dit isoleer.

Opmerking: Die prentjie van die massamens, die Wes-Europese mens, wat die Tweede Wêreldoorlog in die angs vir 'n atoombom aan eie lywe geken het, ken ons seker nog nie so sterk en duidelik in Suid-Afrika en veral in Afrikaanse kringe nie. Niemand kan egter sê dat die prentjie van die ,vierde mens" glad nie in Pretoria of Johannesburg onder Afrikaners of selfs onder Gereformeerdes of selfs onder studente te Potchefstroom sal voorkom nie - of afwesig is in die kerk wat ons ken, in die belydenisklas wat ons gee of selfs in ons eie huis nie. Dit is selfs moontlik dat die prentjie in onsself vorm aanneem. Vermy ons nie ook vandag al die ,persoonlike beslissing”, die persoonlike „ek”, selfs die besef en rekenskap oor eie kerk en eie gereformeerd-wees nie - om liewer te vlug in die rus van 'n kollektiewe ek-begrip, of 'n tradisie-kerk, of 'n Potchefstroomgroepskerk, of die drie Afrikaanse-groepskerk of die Gereformeerde Ekumeniese Sinode soort van groep-gereformeerd wees; of selfs die idee van 'n ekumeniese Christenheid? Wie is nog bereid om self, desnoods alleen, verantwoordelikheid en standpunt in te neem op grond van die Bybel -? Het ons nie eers die advies van 'n professor of 'n klassis of liefs en by voorkeur 'n reglement of besluit van ,die Sinode" nodig nie? Sonder die kollektiewe-ek sorg ek dat ek nie deur 'n standpunt betrokke raak nie. As dit met die groen hout gebeur...?

Op faktore wat aan die Afrikaanse „kerkbesef" in die algemeen nog 'n eie karakter en moontlikheid gee - sou in 'n historiese perspektief afsonderlik gehandel kan word. Daarop kan nie nou ingegaan word nie. Laat ons net in positiewe sin sê dat onder die meer tipies-inheemse volke van Suid-Afrika (d.w.s. dié wat hulle nie kultureel met 'n kultuur buitekant S.A. identifiseer nie en daarmee bedoel ons blanke sowel as nie-blanke Afrikaners of Suid-Afrikaners soos Nguni's, Sotho's, Tsonga's, Afrikaners, Venda's) is daar nogs 'n sterk religie-besef aanwesig. Die omvattende eksistensiële situasie dwing om religieuse beslissings, soos o.a. watter hoop is daar vir $m y$ en vir $m y$ groep? Hierdie vraag openbaar in sy wese 'n religieuse besef waarin die hede aan die toekoms verbind word. As sodanig is dit ook ' $n$ historiese perspektief. Daarbenewens gee hierdie religieuse vraag, wat ten diepste ook die vraag van Luther was, 'n relevansie aan die kerk in hierdie konkrete werklikheid. Dit laat ruimte vir 'n gesonde en heilsame kerkbesef.

Die impotensie van die geïnstitusionaliseerde, onbeweeglike Roomse Kerk om aan Luther 'n antwoord te bied op sy eksistensiële 
vraag hoe kry ek die lewe?, het Luther se religieuse besef juis teenoor sy kerkbesef te staan gebring. Anders en miskien meer Luthers gesê: Luther se besef van die onsigbare kerk het hom juis in 1517 laat besef dat die sigbare instituut van Rome geen kerk meer is nie. Met nadruk kan 'n mens dit so stel: Die eksistensiële vraag van die mens Luther verteenwoordig en verpersoonlik in 'n breër historiese perspektief eintlik die vraag van die destydse Duitse volk en van elk van die dertig Duitse staatjies teenoor die institusionele oorheersing onder die valse teokratiese idee wat geleef het of in die ou Heilig Romeinse Ryks-idee van die keisers - of die van geinstitusionaliseerde ekumene in die Roomse Kerk onder die Pous as die Vicarius Christi.

Die ooreenkoms van hierdie vraag met die eksistensiële vraag na lewe en voortbestaan vandag vir die Afrikaner, die Sotho, die Kleurling, die Tswana, die Zulu, die Xhosa, is duidelik.

Opmerking: Ons kan dus sê dat die evangelie van Jesus Christus 'n antwoord gee op die eksistensiële vraag vir die individu, die volk, ens. Die Voortrekker het in sy eksistensiële nood sonder 'n geinstitueerde kerk en selfs sonder 'n dominee, sy mens-wees religieus verwesenlik in geloof en gebed. So impliseer die religieuse-besef nie noodwendig die geïnstitueerde kerkbesef nie. Die twee is nie noodwendig identies nie. Eersgenoemde is in werklikheid voorwaarde vir lg. sover dit die gelowige betref. By die ,ampsdraers” of „burokrasie" is dit egter omgekeerd. Daar kom die kerkbesef voor die religieuse besef soos dit by Rome tydens die Reformasie duidelik na vore getree het. Die vorm, die organisasie, die instituut is vir hulle voorwaarde vir en selfs identies met religie-besef.

\section{Historiese perspektief op die kerkbesef hang saam met die geskiedenis van die kerkbegrip}

Miskien klink die probleem afgesaag, maar nietemin moet ons al dadelik weer vra: Verstaan alle Afrikaners, alle Gereformeerdes of selfs alle Gereformeerde predikante onder die woordjie "kerk" dieselfde? Weet ons presies elke dag wat beteken die woord "kerk" bv. wanneer jy moet onderskei tussen ,die kerk se taak teenoor die jeug" of selfs wanneer 'n mens hoor van "die jeug se taak in die kerk" of „,die jeug se taak teenoor die kerk" of ons taak ,as kerk" en erger nog ,ons taak saam met die kerk"?

1. In die Skrif is die kerk 'n dinamiese koinonia, 'n liggaam, 'n volk onder die Christus-Koning. Die kerk ontleen sy wese primêr aan die vertikale dimensie, die verhouding tot en die verbond met God. Die organiese, die gemeenskap (koinonia) rondom die evangelie (kerugma) staan voorop. Weliswaar is daar gawes (charismata) van die Koning aan die volk - maar hulle bly organies-een met hulle funksies as bedieninge (diakoniai) binne die funksie van die volk om die Koning in die koninkryk te dien. Die gawes en bedieninge bring die ordelike organisme (liggaam) onder die Hoof (Christus) tot openbaring - maar tog word hulle nie verselfstandig tot instituut nie. Die Skrif ken die begrip diens (vir gelowige en vir voorgangers) 
- maar nie die begrippe kerkraad, klassis of sinode met soveel woorde nie. Om in die Skriftuurlik kerkbeeld te gaan onderskei tussen kerk as instituut en kerk as organisme sou dwaas wees. Jy mag dit moontlik in die begrip kerk kan inlees, maar jy kan dit uit die begrip nie gaan uithaal nie.

2. Die Ou Christelike Kerk ken nog die organiese kerk-wees, terwyl die figuur van die episkopos na vore tree. Die primus inter pares word princeps, maar nog altyd van en gebonde aan die bepaalde plaaslike organisme, die kerk (vergelyk by Ignatius van Antiochië).

3. Gedurende die Middeleeue ontwikkel die magtige Roomse Kerk. Die Romeins-Westerse talent vir organisasie, konstituering (vgl. Romeinse regspraak) bou 'n corpus, 'n institusionele-struktuur - tydens Innocentius III self die meerdere van enige ander politieke of maatskaplike struktuur op die aarde. Die ,kerk" as instituut en as abstraksie skuif volledig in bo die lidmaat en tussen die ,leek" en die Koning Jesus Christus. Die organisme ,kerk" is volledig gesplits en sy institusionele karakter en organe buite en bo die organisme ,as 'n Kerk" verselfstandig. Die proses voltrek hom so kompleet en geweldig imponerend dat feitlik alle Westerse en aanverwante denke vandag nog onder KERK niks anders as 'n aards-sigbare instituut, verpersoonlik in sy amptenare, ampte of organe kan en wil verstaan nie. Daarmee is die Bybelse kerkbegrip volkome gesekulariseer tot 'n Instituut en Ampsdraers.

4. In die Renaissance (sowel in klassiek-heidense humanisme as in die Reformasie) reageer die individu, „die leek”, teen die absolutisme van die Middeleeuse Kerk- en Amp en Ampinstituut.

5. Maatskaplik en polities verander die strukture. Nuwe stedelike en nasionale strukture met vrye bewegende individue kom op teenoor die statiese Kerkkolos en teenoor die feodalisme met sy hiërargiese en bevoorregte klassepatroon.

6. Luther lei die Reformasie in met 'n kompromistiese kerkbegrip. Die wese van die Skriftuurlike Kerk verstaan hy uitsluitend onsigbaar. Deur die geloof bestaan dit in die harte van gelowige individue. Daarteenoor het Luther die sigbare geinstitueerde kerk (op voetspoor van dié van Rome) gesekulariseer. Dié kerk is 'n struktuur binne en vir die corpus christianum wat swaar leun op die ius patronatus. Dit word deels kerklik en deels polities ,georganiseer" soos dit pas en so open dit die pad vir die kollegialisme. Nog steeds is die breuk in kerkbegrip voltrek: wesenlike kerk-wees staan los van en daarom ook dikwels teenoor die instituut. Luther het immers ook teenoor die kerk as instituut (Pous) en staat (keiser) op die Ryksdag te Worms te staan gekom om die ware onsigbare kerk te dien.

7. Calvyn word as, let wel, predikant in 'n organiese verband met die kerk na Genève geroep. 'n Konflik kom na vore wanneer juis die kerk-wees in gedrang kom en die stadsraad (parlement) van Genève op sterkte van die corpus christianum en ius patronatus vir en in die kerk wil voorskryf. Om die kerk se wense as selfstandige gelowige gemeenskap onder die soewereiniteit van Christus te red 
ontwerp Calvyn sy Kerkorde. Daarin gaan hy uit van die verskil in roeping wat God laat kom ten opsigte van kerk en stad; die sigbare kerk met sy bedienaars verkeer in eenheid met die onsigbare kerk onder die Koning Christus. Wanneer ons egter vandag van abstrakte dinge soos ,,kerk" en ,staat" praat, moet ons onthou dat „owerhede" vir Calvyn nie 'n ,begrip" maar konkrete persone soos Frans I was wat hy met sy Institusie in 1536 kon aanspreek. Daarom het Calvyn 'n sekere voorkeur aan 'n aristokratiese regeringsvorm op politieke gebied gegee. Soos die konkrete ouderling tegelyk opsiener was, so was 'n konkrete persoon tegelyk owerheid.

$\mathrm{Om}$ effektief teen die geïnstitusionaliseerde ius patronatus op te tree, moet ook die bedienaars in die kerkraad institusionaliseer. Daarom is naas die konstituwe reg ook die institusionele reg nodig - die institusionalisering bring egter mee dat die konsistorie of kerkraad in 'n sekere sin die plek van die organiese bedienaars (episkopoi) inneem. Hoewel die term presbiteriale kerkregering in sy wese heenwys na die Skriftuurlike ouderling, word gesê dat Gereformeerde kerkregering ,presbiteriaal" is omdat dit primêr van die institusionele kerkraad uitgaan (vgl. Kerkorde van die Geref. Kerk in S.A. 1968, p. 11). Dit is tog iets anders as om te sê dat die presbiteriale kerkregering primêr (soos die Skrif) van die ouderling uitgaan. Om die kerkregering basies op die ,kerkraad" te fundeer, bring tog ' $n$ institusionele kerkbesef na vore teenoor die Skrif wat die kerkregering toewys aan die herders, die aristokratiese episkopoi, die ouderlinge. Opmerklik genoeg het die begrip „,kerkraadslede” ook al by ons ingeburger. Die kerkraad is eerder as sy „lede”. Dit openbaar 'n bepaalde kerkbesef. Soos wat die begrip ,owerhede" vir die mens in die sestiende eeu primêr die persoonlikhede soos landhere, vorste en konings voorgestel het en vir ons vandag abstrakte staatsbegrippe verteenwoordig, so verkry ook begrippe soos kerk, kerkraad ens. gaandeweg 'n abstrakte betekenis, so veel so dat die woord kerkraad in die sestiende eeu niks anders as byeenkoms van ouderlinge kon beteken nie, en by ons vandag glad nie lekker smaak vir 'n ,ouderling-vergadering" nie. Wanneer ouderlinge in 'n klassis of sinode vergader sou ons dit „,kerkvergadering” maar nooit ,kerkraadsvergadering" kan noem nie - omdat die begrip geïnstitusionaliseer het.

8. Ondertussen het die herleefde klassieke filosofie en metafisika in Wes-Europa laat soek na die idee agter die verskynsels. Sodoende kom die idee op van 'n sentrale abstrakte staatsgesag agter en in die Koning. Onder leiding van die Liberalisme en Aufklärung word die gesag metafisies geregverdig en oorgedra na die individue wat hulleself verenig in 'n kontraktuele staat d.m.v. 'n demo-krasie. Hierdie abstrakte staatsgesag wat die gemeenskapsgesag uitdruk, verdring nou alle mindere en plaaslike gesagstrukture. Hobbs het in 1630 met sy Leviathan aan hierdie gedagte uitdrukking gegee. Die abstrakte staatsidee sluk gaandeweg die eertydse magte en bevoegdhede van die landhere, vrystede, mindere strukture en uiteindelik selfs van die owerhede in. Nog verder sluk hierdie owerhede van Wes-Europese Ryke op hulle beurt selfs die owerhede van 
ander lande in die proses van kolonialisme in.

Die ekwivalent van hierdie abstrakte staats- en magsidee verloop (net soos in die Middeleeue) parallel met die opkoms van 'n abstrakte kerkidee. Waar in die Roomse Kerk die Pous nog min of meer figureer het soos die Middeleeuse vors, tree in die kollegialisme hierdie gemeenskapstruktuur en -gesag in die kerkbegrip sterk na vore.

9. Die Kollegialisme vorm ten diepste 'n kompromis van verskillende historiese elemente en sy kerkbesef en kerkbegrip word daardeur ten nouste beïnvloed. Eerstens was daar die valse teokratiese gedagte van Konstantyn die Grote, Karel die Grote en die keisers van die Heilig Romeinse Ryk m.b.t. die corpus christianum en die ius patronatus waardeur die owerheid (gedurende die Middeleeue die landheer) moet sorg vir die geestelike welsyn van die onderhoriges; verder was daar die valse opper-kerklike-idee van die teokrasie waar die kerk (Pous) sy mag uitoefen deur middel van sy verteenwoordigers of kerklike owerhede; daarbenewens tree by Luther 'n breuk in die wese van die kerk na vore, wanneer hy dualisties die eintlike kerk onsigbaar en die sigbare kerk (instituut) as 'n tydelike en verbygaande verskynsel beskou. Hiernaas of waarskynlik in verband hiermee kom dan die idee van 'n abstrakte ,kerk" agter die sigbare verskynsel ,kerk" sterk na vore soos wat ons dit veral vandag in die twintigste-eeuse woordgebruik aantref.

Hier word ook veral natuurlik die ,Sinode-instituut" as Kerk gesien. Verder is enige funksionaris van die kollegium in 'n sekere sin verteenwoordiger van die ,kerk”, sodat daar gepraat word van die kerk se prediking, kerk se kategese, kerk se soektog, kerk se standpunt, ens. Die metafisiese kerk-idee beheers alle plaaslike en ander verhoudinge. Die sigbare instituut, kerklike vorme het egter ten diepste niks of min te make met die eintlike kerk, die verhouding van die individu tot Christus. Gevolglik kan die verskynsel van Staatskerk, Volkskerk, institusionele vorm, los van die eintlike kerklike wese na vore tree.

Die kerkbesef kom veelal soos volg na vore: Die gelowige het 'n religieuse band met Christus en die gelowige het 'n institusionele verhouding tot 'n kerk wat hom 'n deel aan hierdie wêreld en tydelike verhoudinge gee en wat hy dus as „my” of „ons kerk” ken.

\section{Die balas van kerkbegrip in Suid-Afrika}

9.1. Suid-Afrika het 'n kosmopolitiese invloed ondergaan in sover dit sy kerkbegrip betref. Aan die een kant het 'n Luthers-kollegialistiese invloed baie sterk sy stempel in 1816 in die Suid-Afrikaanse kerklike lewe afgedruk. Daarnaas is daar onmiskenbaar invloede vanuit Skots-Presbiteriaanse, Anglikaanse, Ned. Hervormde kringe aanwysbaar. Veral die reglemente van die Kaapse Kerk sedert 1824 en verhoudinge tussen Kerk en Staat kan moeilik sonder hierdie begrippe begryp word. Die Ned. Herv. Kerk in die Z.A.R. in 1853 sluit gedeeltelik hierby aan.

Wanneer ' $n$ mens let op die kerkbegrip by die Afskeiding in 
1834 in Nederland en selfs in 1859 by die vormgewing aan die Gereformeerde Kerk in S.A., merk 'n mens dat die kerkbegrip as sodanig nie omlynd en gesuiwerd na vore tree nie. In 1859 tree kerkbesef as 'n kardinale motief na vore. Dit sentreer egter rondom die Gereformeerde-eksistensie en kom neer op 'n instituering met die oog op kerk-wees en nie op die represtinasie van een of ander instituut nie.

9.2. Calvyn het via die Franse en Nederlandse agtergrond op die Kaapse kerklike lewe invloed uitgeoefen. Hierdie invloed dateer hoofsaaklik voor 1795. Dit het ook hoofsaaklik na vore getree in die leefwêreld van die plaaslike gemeente, omdat die gemeentes nie kerklik nie dog deur die HOIK as staat (Politieke Raad as patronaat) versorg is. Wanneer die Sinode van die Gereformeerde Kerk in S.A. in 1863 egter die Dordtse Kerkorde aanvaar, tree bepaalde Calvinistiese kerklike beginsels en -besef na vore. Dit is gedeeltelik institusioneel verwesenlik, maar andersyds moes die kerk eintlik reformatories hierdie kerkbesef in die wêreld van S.A. weer verwerf, indra en beleef. Gereformeerde beginsels het invloed uitgeoefen op Gereformeerde mense - maar tipies Suid-Afrikaanse geclagtes en erfenisse het ook invloed uitgeoefen op die kerkbesef van Gereformeerde mense binne die GKSA sodat die kerkbesef nie suiwer Calvinisties kon wees nie.

9.3. 'n Definitiewe invloed in die kerkbesef in SA stam ook uit die Nederlandse Doleansie o.l.v. dr. A. Kuyper in 1886 en daarna. Hierdie invloede is duidelik aanwysbaar in die GKSA (en ná 1924 met die besoek van H. H. Kuyper en die daaropvolgende saak teen prof. J. du Plessis ook in die NGKSA). Die klemtoon word al sterker gelê op die instituut met sy vergaderings en dié vergaderings word dikwels dualisties gesien as 'n plaaslike kerk o.l.v. kerkraad en 'n ,algemene kerk" of kerkverband o.l.v. 'n Sinode.

9.4. Hierdie geestelike agtergrond veroorsaak 'n breuk in die kerkbegrip tussen die sigbare (institusionele) en onsigbare (wesenlike as geloofseenheid met Christus) Kerk. E.g. word uitsluitlik met die sigbare fenomeen geïdentifiseer - l.g. word aan elke individu oorgelaat. Gevolglik tree 'n duidelike schisofrene-kerkbegrip na vore waarin die individu se kerkbegrip teenoor sy begrip van homself as 'n gelowige in verband met Jesus Christus te staan kom. Dit word gevolglik 'n sjibbolet om te vra na die kerkverband, ,waar is hy lidmaat" - eerder as om te vra na sy belydenis en persoonlike integriteit en oortuiginge (vgl. op skoolkomitees, by aanstelling van onderwysers, in die kabinet, by Geloftedagkomitees, ens.).

\section{Kerkbegrip in GKSA histories besien}

Dit is andermaal baie moeilik om presies te probeer omlyn hoe die Gereformeerdes in 1859 die begrip kerk beleef en verstaan het. Veral (1) vóór Postma gekom het en (2) o.l.v. hulle dominees. Dit sou 'n indringende dokumente-analise vereis.

In die algemeen kan ' $n$ mens tog opmerk: Die begrip „kerk” is oorwegend gesien as 'n plaaslike organisme. Die gebeure in 1859 
rus op konkrete inflammasie wat oor dekades in gemeente(s) na vore getree het met betrekking tot liturgie, prediking, verhouding tot ,gekleurden", kerkregering, nuwe leer, toleransie teenoor vreemdes maar sensuur op diegene wat konserwatief wou bly op gesag van die Sinode(s), (Ringe) en dominees wie se optrede en gesag in stryd met God se Woord aangevoel is. Die Kerk wat hulle in 1859 verlaat het, was dié wat hulle geken het en nie 'n abstrakte NGK of NHK nie. Die ,naam" van die instituut was geen punt in die geding nie.

Hulle het die ,kerk” in hulleself gesoek en dit nie geobjektiveer en met kerkvergaderings of ampsdraers gelykgestel nie. Hulle het bv. nooit eers oorweeg dat wanneer hulle tot 'n gemeente gestig word hulle dalk nie as kerk nie maar as 'n ,sekte" beskou sou kon word nie. Dat hulle kerk-was en kerk-doen het in alles vasgestaan.

Hulle het die verhouding tot die dominee gemeet in terme van die bediening wat hy op sterkte van die Skrif aan en in hulle as kerk verskuldig was. Toe hy, later gesterk deur die Ring (1841 e.v.) en uiteindelik die Sinode (1847), hom juis teen hulle gekeer het en die tug teen hulle wat hulle op die Skrif beroep het, aangewend het, het hulle as 't ware uitgesit gevoel, omdat dwang toegepas is sonder dat bewys is dat hulle teen die Skrif, die Woord van Koning Christus, gegaan het. Die besluit van die Algemene Kerkvergadering van die NHK in Pretoria op 12.1.59 het dieselfde indruk gelaat.

Die lang tyd van lojale erediens-bywoning (1836-1858), sonder dat hulle meegedoen het aan die gesange-liturgie of die nagmaal (op grond van die groepsensuur deur die Ring van 1841 in die herderlike brief uitgeoefen), toon dat die ,kerk" vir hulle 'n lewensgemeenskap was, waaraan hulle lank, selfs met smarte, vasgehou het. Dit word beklemtoon na die kerkstigtings in 1859. Hoewel die meeste (miskien almal) slegs sesweekliks of driemaandeliks eredienstig byeen gekom het, het hulle kerk-gevorm, kerk-gewees en kerk-gebly deur (1) sterk identifikasie met die gemeente; (2) absoluut getroue daaglikse en Sondagse huisgodsdienste en katkisasies op plase en in dorpshuise; en (3) ontwyfelbare aanvaarding van hulle Christen-identiteit en die Skrifgesag op alle terreine: moreel, polities, ekonomies, maatskaplik, ens., met gepaardgaande deugde van hoë sedelikheid, integriteit, eerlikheid, verantwoordelikheid, gasvryheid, barmhartigheid, ens. Hierdie karaktereienskappe wat individueel en in groepsverband na vore getree het, het te doen met ' $n$ werklike kerkbesef as 'n verhouding tot Christus en geensins met ' $n$ verhouding tot ' $n$ instituut nie. Die instituut moes net diensbaar wees om die wesenlike kerkbesef uit te leef.

Kortom, kerk-wees was 'n geïntegreerde faset van hulle menswees, al het dit gepaard gegaan met ' $n$ minimum van in-die-eredienswees - hoewel ironies genoeg juis 'n liturgiese kwessie nl., die Gesange, oënskynlik en oppervlakkig beskou na die rede van hulle afskeiding lyk (so geĩnstitusionaliseerd-versmald het die oordeel dan ook inderdaad oor hulle kerk-wees geword). Die identifikasie wat tot die afskeiding in 1859 gelei het, was volledig religieus gemotiveerd. Daarom was hulle identifikasie meer as 'n tradisie van die 
kerk-van-die-boer, kerk-van-die-vaders of kerk-van-die-staat. Die identifikasie van kerk-wees is aan hulle mens-wees en Christen-wees ontleen. Kerkstigting het dus geen vraag in 1859 na vore gebring t.o.v. hulle volk-, ras-, of staatsverbondenheid nie.

Vandag kom die vraag op: Het die begrip kerk-wees en Gereformeerd-wees nie versmal tot 'n in-die-erediens-wees nie? Of hoogstens daarby: goeie bydraes gee „vir die kerkraad” (sommige sê selfs virdie-Here!) om geboue op te rig, orrels te koop of ramings te betaal nie? Moontlik word kerk-wees nog verder versmal tot mooi luister wanneer die Kerkraad of die Sinode besluit het oor sake soos geen vrymesselaars nie, geen lotery nie, geen dans nie, ens.? Hoe baie hoor 'n mens in kerkkwessies ,die sinode het so besluit" en hoe min hoor mens nog, in die Woord lees ons..."!

Indien 'n mens vra na die rede vir hierdie verskynsel van 'n versmalde kerkbegrip, sou daar seker baie historiese faktore in aanmerking geneem moet word: verstedeliking, onderwys, ondertrouery, deurwerking van Engelse Deïsme en Afrikaanse piëtisme, Kuyperiaanse filosofie oor soewereine terreine met 'n kompartement vir die kerk naas die staat, skool, kultuur en maatskappy, primêre identifikasie van Christen-wees met blanke ras, politieke partye, europa, ens.

Ek meen egter dat een belangrike faktor vir die versmalde kerkbesef die kerk self sal wees en by name die rol wat dominees, kerkrade en kerkvergaderings gespeel het om die kerk-wees te versmal tot 'n verhouding rondom die erediens, traktement vir predikante, die bou of reparasie van kerkgeboue en pastorieë, ens. Daarmee is dan eintlik die sg. "terrein" vir die kerk aangetoon. Al wat verder nog eintlik sou kon bykom is ' $n$ in-homself-opbouende en -opgaande aktiwiteit wat sentreer rondom die klassis en sinode waar tussen die Part. Sinode vir baie los hang, omdat hy nie lekker ,institusioneel" wil smaak nie.

\section{Kerklike tendense wat kerkbesef in die periode $1859-1973$ kon afgetakel het}

1. Die proses van institusionalisering

1.1. Ons moet onderskei tussen institueer ('n kerk stig, vormgee, konstitueer) en institusionaliseer. E.g. geskied ter wille van die gemeenskap (koinonia). L.g. vind plaas met die oog op die instituut self. Ek herinner in hierdie verband na die voordrag van dr. C. J. Alant: 'n Organisme word geïnstitueer op grond van die diens wat hy aan 'n gemeenskap lewer of pretendeer om te lewer; gaandeweg (histories) begin hy al meer in sy eie institusionele bestaan, profiel en belange opgaan en sentreer dus hoe langer hoe meer rondom en ter wille van sy burokrasie. Op kerklike gebied sou institusionalisering aan die dag getree het wanneer die kerk-wees, plaaslik, klassikaal en sinodaal opgaan in kerkregering met die oog op die instituut self; finansiële en ander administratiewe verpligtinge; inisiëring van alle kerklike aktiwiteite d.m.v. die kerkraad, kerkraadskommissie of een of ander besluit van 'n ,meerdere" vergadering; gebrek aan 
inisiatief by lidmate uit vrees dat die dominee, die klassis of 'n sinode nie daarvan sal hou nie; aksies, ens. met die oog daarop om 'n antwoord te kan verstrek aan 'n klassis by visitasies of deur gemeenteverslae; bedrywigheid in die gemeente, kerkraad op grond van en met 'n beroep op sinodegesag, sinodereglementerings; geleidelike toelating dat alle fasette van die plaaslike kerk-wees inskuif onder klassisse, ens.; botsings en wrywing tussen predikante en ouderlinge of kerkraad en lidmate oor kerkraadsbesluite; die gebruik van art. 27 K.O. of ander metodes om van sg. "lastige” elemente in die kerkraad ontslae te raak of stemme van die klassis of die sinode weg te hou, of daar stil te maak of te elimineer deur politiekery; die soek en die gryp na formele redes as 'n argument waarom 'n lastige voorstel of appèl van die tafel afgehou kan word; die ontduiking van die plig, roeping en verantwoordelikheid om op 'n kerkvergadering in die lig wat daar gekom het 'n besluit te neem; die neiging om kerklike oordele en verantwoordelikheid afhanklik te maak van kommissies wat eers moet ,gestudeer" het wat dikwels daarop neerkom dat ' $n$ vergadering gebind word deur die bevindinge van 'n kommissie; kortom, wanneer 'n mens dikwels na die agenda van 'n sg. breë kerkraadsvergadering, klassis of sinode kyk, sou jy jou kon afvra wat het die sake wesenlik met kerkwees, d.w.s. met luister na en antwoord op Jesus Christus en die Woord van God te doen - en hoeveel sake is 'n blote institusionele gedoen - die monster van instituut-wees sonder om werklik primêr met die kerkvan-Christus-wees besig te wees. Veral die begrotingsposte en sake waarvoor finansieel bestee word deur kerkrade en kerkverband is in hierdie verband veelseggend.

\subsection{Die aktualiteit van institusionalisering}

J. C. Hoekendijk (a.w., p. 13): „Ons werk is zozeer geinstitutionaliseerd geworden dat beweeglijkheid en spontaneiteit in het gedrang komen.

,"Zelfs in de jongere kerken krijgt - helaas - de tweede generatie christenen een onbeweeglijke structuur. En voor een volgende generatie is het christelijke leven dikwijls al een alledaagse routineaangelegenheid geworden... We merkten iets van angst dat de kerk haar gezicht verliest of uitgelopen wordt deur machtige rivalen. Bladerend door evangelisatie brochures komen we woorden tegen als ,communistische dreiging'...

„Laten wij er niet om heen draaien: de oproep tot evangelisatie is vaak ongeveer het zelfde als een oproep de ,christenheid' te herstellen, het Corpus Christianum, als stevig-geintegreerd cultuurcomplex, bestuurd en beheerd door de kerk. En de urgentie berust vaak alleen maar op een opgejaagd gevoel van onveiligheid, doordat het zekere bestaan van de kerk in gevaar komt;...

„Eigenlijk is ,evangeliseren' dikwels ,een bijbelsche camouflage voor wat beter ,het terugwinnen van kerkelijke invloed' genoemd kan worden. Vandaar de overdreven eerbied voor statistieken en de onverzadigbare kerkelijke honger naar steeds nieuwe levensterreine..."

Ondertussen het die gelowige egter te doen met 'n gereduseerde 
kerkbegrip waarin feitlik net preek en sakramente fungeer - en dit het tot ons verbasing ,geen hervormende kracht meer" (p. 14). So besig as wat dominee, kerkraad, klassis en sinode is om die gesag van kerk-as-instituut-wees op te hou, so sterk voel die lidmaat hom in die koue gelaat. Die preek laat dit ook per slot van sake maar aan hom of haar oor om heen te gaan en te gaan vra: Waar kan ek kerk wees? 'n Mens wil beweer dat die institusionalisering van die kerk van die Reformasie dieselfde breuk voltrek as wat in 1517 in die Roomse Kerk bestaan het: aan die een kant die groot bedrywige instituut met kerkbou, salarisse, ekumene en dalk selfs wêrelddiakonaat en aan die ander kant 'n verhongerde en honger „leek".

Die geskiedenis aan die einde van die Middeleeue het die Kerkreformasie veroorsaak. In ons eie tyd aanskou ons eintlik reeds weer baie dieselfde skrikwekkende beeld. Groot staatskerke van weleer het nog 'n indrukwekkende organisasie maar min belangstelling van die lidmate op kerklike terrein. Hulle leiers en voorgangers is bedrywig op politieke gebied, met die oog op 'n sosiale revolusie, in diens van die afgod „change”, en tegelykertyd is hulle gemeentes of parogieë morsdood. Daar is weinig van werklike kerk-wees onder die lidmate te bespeur. Ons mag in hierdie stadium sê dat hierdie beeld van die twintigste eeu hom nog nie by ons openbaar nie maar die vraag is of tekens van hierdie spookbeeld nie ook al by ons om die deur loer nie?

1.3. Institusionalisme vernietig ware kerkbesef omdat dit die begrippe kerk as instituut en kerk as organisme skei

1.3.1. Die begrippe kerk as instituut en kerk as organisme is slegs dienbaar wanneer in gedagte gehou word dat die instituut organisme en die organisme ook geïnstitueer is. Beide begrippe gee slegs perspektiewe op dieselfde geïntegreerde werklikheid nl. die een kerk.

1.3.2. Dit is uit historiese perspektief opmerklik dat die kerk geweldige energie, momentum en potensiaal openbaar het, waar hy organies na vore getree het bv. waar Postma in 1859 te doen kry met 'n petisie van 12 voorgangers in die gemeenskap wat pas die gemeenskap met die NHK opgesê het. Daardie energie voer deur Transvaal, die O.V.S. en Noordoos-Kaapland.

1.3.3. Dieselfde gebeur wanneer De Cock in 1834 of Kuyper in 1876 deur die ,kleine luyden" tot beweging gebring word en as voorganger-organe die aksie lei in die stryd vir die handhawing var. die Belydenis. Institusioneel het die stryd die faset bevat: dit gaan oor bewoording van 'n Formulier; oor ondertekening; verhouding van 'n kerkraad tot 'n klassisbestuur; oor attestasie, ens. Nietemin is die organiese kerk-energie sterk genoeg om nuwe institute op te stoot VU (1876), A.R.-party, Skool-met-die-Bybel, Geref. Kerken van Nederland (1890), talle koerante ens., ens.

Tipies aan Kuyper se filosofie oor "soewereine terreine" waarin hy die ,kerk" ook sekulariseer tot 'n fenomeen soos en naas die 
huis, skool en party, ontstaan 'n menigte afsonderlike gereformeerde aksies. Gevolglik is dit onvermydelik dat die tipies Nederlandse begrip van kerk-wees eng rondom Kuyper se terrein vir die ,kerk” vereng, wat opgaan in eredienste bywoon, kollekteer hiervoor en daarvoor, preke of predikante bespreek. - Na buite moet telkens weer ,op elke terrein" geïnstitusionaliseer word in repeterende verenigings nl. manne- en vroue-, seuns- en dogters-, geref. musiek-, toneel-, sending-, sportverenigings, ens., ens. - 'n repeterende breuk binne die gereformeerde lewe en ' $n$ repeterende breuk en duplikasie t.o.v. wat reeds in die maatskappy bestaan.

Die kerk as instituut kom dus volledig naas die aksies van die sg. kerk as organisme te staan en lg. aksies wat gebore is uit 'n beroep op die kerk-as-organisme kom op hulle beurt te staan naas ander reeds soortgelyke bestaande verenigings. In Nederland ontstaan as gevolg van verdelinge binne die kerk die gereformeerde. gesindtes dan ook nog weer selfs parallelle verenigings vir en rondom elke gereformeerde kerkgroepering.

1.3.4. In S.A. het die breuk, wat ek 'n schizofrene kerkbegrip wil noem, waarvan die wortels diep in die Romeinse Ryk en corpus christianum-gedagte, die Roomse Kerk, die Renaissance, en die Lutherse Reformasie lê, op twee wyses sy stempel swaar gedruk:

1.3.4.1. Dit veroorsaak die eienaardige vervlegtheid van die politiek en religie, kerk en staat in die HOIK en Kaapse Kerke, die Anglikaanse en Skotse Kerke en die Nederlandse Herv. Kerk op die Reglement van 1816. Dit het uit die K.O. van de Mist (1804), die Reglemente van die NGK Kaap (1824) en dié van die NHK (1853) gestraal. Die invloed daarvan is dikwels uit gesprek, term en geskrif ook in die GKSA gevoel. Die Kerkbegrip rus wesenlik op die institutêre; gaan op in die organisatoriese; word beheers en gedra deur die struktuur van 'n abstrakte kerk-fenomeen vir maar eintlik buite die gelowige self - eintlik 'n huis vir die „lidmaat" om kerklik in te gaan woon.

1.3.4.2. Die stigting van die GKSA in 1859 is bewerkstellig deur 'n momentum rondom 'n geestelike motief nl., die diens, leer en tug soos beliggaam in die Dordtse Sinode en die beginsel van 'n vrye kerk t.o.v. die staat. Die institusionele (Postma K.O. 1859 en D.K.O. 1863) kom by om hierdie momentum te dien. Die GKSA het sy stem waar nodig regstreeks laat hoor in die politieke state i.v.m. konstitusionele, onderwys, vakansiedae, en ander kwessies. Origens het elke Gereformeerde met sy geloof en volgens sy lewensbeskouing opgetree in die natuurlike sosiale institute, volksvergaderings, kommando's, ens. Hy het nie sy eie Gereformeerde volksvergadering, kommando of aparte komissie gaan stig nie. In hierdie opsig verskil die ontwikkeling nogal aanmerklik van dié in Nederland.

$\mathrm{Na} 1890$ werk die filosofie van A. Kuyper e.a. en voorbeelde soos die in die VU ook deur in Gereformeerde kringe. Verskillende afsonderlike aksies vir onderwys word geleidelik onttrek en naas die kerk geïnstitusionaliseer d.m.v. kommissies en komitees vir C.N.O., V.C.O., later P.U.K.-komitees, Calvinistiese aksies, ens. Aanvanklik dra die energie van persone, mense (voorgangers-saam-met-lidmate) 
hierdie aksies. Geleidelik stagneer dit egter in die institusionele. Vandag sal geen kerkraad meer daaraan dink om te gaan besin oor bv. gedifferensieerde onderwys as 'n produk van die pragmatisme en tegnokrasie waarin die opleiding-vir-beroep i.p.v. die vorming van die persoon oorheers nie. Dit sal verwag word dat dit uit 'n geïnstitusionaliseerde kring iewers buite die kerk (bv. die PU vir $\mathrm{CHO}$ ) vandaan mag kom.

1.3.6. Na die besoek van H. H. Kuyper (1824) en die J. du Plessis-saak (1829) het die Kuyperiaanse terminologie ook sterker in die NGK, veral in die Noorde, na vore getree. Op klank en woord af, geoordeel aan die institusionele, het die verskille vervaag. Die NGK is op Nederlandse model meer ,gereformeerd" georganiseer (ijO 1962) en die GKSA raak meer sinodaal geinstilusionaliseer. Persberigte en samewerking met die SAUK bring dieselfde terminologie na vore; "kerk" en ,gemeente" word radikaal geskei; persone tree „namens" die kerk op, ens. Soms is al gesê: die GKSA beweeg net 25 jaar agter die NGK. Wat sou daarmee bedoel wees? Ek meen dit dui op die proses van institusionalisering.

In 1859 was die GKSA die naaste aan 'n geïntegreerde kerkwees; die instituut en die organiese, die liggaam, die volk, was geïntegreer. Teen 1973 het die institusionele duidelik op die voorgrond getree: die organiese sentreer om, in en rondom die instituut. Sou hierdie bewering te ver gaan? Wat sou die Gereformeerdes egter sê? Wat beteken kerk-wees en kerk-doen vir die lidmate volgens die indruk wat hulle wegdra uit alle kerklike aktiwiteit plaaslik en ,in verbande"?

1.3.7. Die Schizofrene kerkbegrip openbaar hom in die aktuele leefwêreld van die kerk in 1973

Die gangbare kerkbegrip in die leefwêreld van die GKSA is dualisties: instituut en organisme; teorie en praktyk; plaaslike kerk en sinode-kerk; gemeente en kerk; dominee en kerkraad; kerkraad en daarteenoor gemeente; gemeente en daarteenoor klassis of sinode; ONS (instituut) KERK en HULLE (instituut) KERK.

Wanneer die deursnee Gereformeerde lidmaat gevra sou word om die kerk te definieer, sou slegs enkeles dit kon doen in terme wat aansluit by die Skrif, Calvyn, K.O., N.G.B., of iets dergelyks. Dominees wat teologiese opleiding gehad het, mag die definisie suiwer weergee, maar sal in sy preke en gesprekke dalk om verstaan te word, moet aansluit by die gangbare, populêre kerkbegrip en terminologie wat in omloop is.

\section{Samevatting}

1. Kerkbesef het te doen met die houding teenoor kerk en kerkwees. In die kerk speel houdings 'n groot rol: interpersoonlik, maar ook houdings t.o.v. die Belydenis, aktiwiteite, besluite, ens. Houding beteken dat elke lidmaat 'n sekere opvatting oor die bepaalde aspek het. Houdings kan verskil: van neutraal (apaties) tot vyandig of tot sterk identifikasie. Die psigologie aanvaar dat die 
houdings ontstaan uit en bepaal word deur die sosiale omgewing, gesin, groep, skool, kerklike milieu, ens. Meer verbreide houdings is vatbaar vir min verandering. Houding het dus baie te doen met die waarde waarvoor 'n sekere instelling staan. Vanuit historiese perspektief moet ' $n$ mens die vraag na houding soos volg formuleer: voel die lidmaat van 1974 hom nog so betrokke by kerk-wees en gereformeerd-wees as in 1859? Identifiseer hy hom met die Belydenis, die kerkregering, die liturgie, die aktiwiteite, die besluite en handelinge van kerkraad en meerdere vergaderings?

2. Die kerkbesef in historiese perspektief bring vervolgens die vraag na motivering na vore

Eerstens moet gevra word of die Gereformeerde gelowige persoonlik in 1974 sy kerk-wees in nou verband sien met sy Christenwees. Die verhouding tussen die gelowige en Jesus Christus is primêr. Dit is selfs nie vanselfsprekend dat die gelowige hom met die kerk sal identifiseer nie. Aan die ander kant is dit moontlik dat juis die primêre verhouding tussen die mens en Jesus Christus swak en verbreek kan wees, terwyl die persoon om ander redes 'n sterk formele institusionele band met die kerk daarop wil nahou. In beide gevalle sou die kerkbesef nie 'n toets volgens Skrif en Belydenis deurstaan nie.

Nida (Lux Mundi, nr. 3, p. 15 e.v.) wys daarop dat die mens ook in ' $n$ sekere sin die religie en die kerk benader met 'n ekonomiese model. Hy vra natuurlikerwys, wat beteken die kerk vir my? Wat het ek presies daaraan? En hierdie motivering is van die grootste belang. Motivering vra immers na waarde. Al sou hierdie waarde nie materieel wees nie maar geestelik, word die mens gemotiveer wanneer hy weet dat die kerk waarde het. Die behoefte van die mens en gelowige en die waarde wat aangebied word tot bevrediging van daardie behoefte, staan in die nouste verhouding tot mekaar waar kerkbesef gevorm word. Nida sê (p. 21 e.v.): „In the final analysis, many people are rejecting institutional christianity because they do not feel that the cost of the church is commensurate with the needs that are fulfilled... It is important to recognize, however, that in this reaction against institutional forms of christianity, there is, nevertheless, a continuing and greatly increased interest in the Bible... This rejection of the Western forms of christianity, while retaining loyalty to the Bible, is especially conspicuous in many of the separatist movements in Africa and Asia. People seem to feel at home with the Scriptures, but are alienated from the forms of Christendom with which they have become acquainted".

In die ouer en in die jonger kerke sal baie deegliker aandag gegee moet word aan hierdie verhouding tussen die lidmaat en die institusionele en bepaaldelik dat die kerklike instituut hom op 'n gemotiveerde en nie op 'n paternalistiese wyse by die mens moet aandien nie. In die jong kerke kom die probleem nog sterker na vore omdat daar 'n vreemde instituut aan mense gebring word wat ander behoeftes het. 
Die lidmaat van die ouer kerk is in baie opsigte vandag ook uit sy plaaslike ligging van weleer geruk (vgl. verstedeliking). In die stad soek hy nog na iets van die lokale. Die plaaslike kerklike instituut moet hom baie deeglik rekenskap gee hoe 'n belangrike funksie hy kan vervul. Dieselfde gebeur eintlik met die heiden wat die Christelike geloof aanneem. Ook hy bevind hom plotseling eintlik in 'n losgerukte posisie en die plaaslike kerk moet vir hom 'n heenkome bied. M.a.w. die moontlikheid dat die kerkgemeenskap 'n bepaalde behoefte moet vervul. en sodoende waarde vir die mens moet hê, is steeds baie duidelik.

\section{Calvyn het sterk nadruk gelê op die vertikale motivering}

Die gelowige en lidmaat moet perspektief hê op die stryd van Christus teen die Antichris. Vir Calvyn was dit duidelik dat die kerk 'n „Entscheidungskarakter” (H. Berger, Calvinis Geschichtsauffassung, Zürich, 1955, p. 73) dra. Die Antichris kom selfs in die kerk voor. Daarom moet die gelowige met 'n ,inner Kirchlichkeit" gemotiveerd wees om die stryd teen die Antichris vol te hou en die kerk suiwer te bewaar. Die kerk kan dan nie 'n statiese struktuur met ' $n$ bepaalde naam wees nie, maar is 'n gedurige dinamiese gemeenskap wat in 'n altyddurende strydsituasie verkeer. Calvyn waarsku gevolglik baie sterk teen „Falscher Sicherheit”.

Dit spreek vanself dat hierdie dinamiese kerkkarakter met 'n sterk vertikale motivering, eintlik radikaal teenoor institusionalisering te staan kom. Sou dit verkeerd wees om te sê dat die kerkbegrip in 1974 in baie opsigte gehorisontaliseer, gesekulariseer en gestagneer het? Opereer die hele problematiek rondom kerkeenwording nie ten diepste met 'n statiese kerkbeeld nie? Is die vertikale motivering nie vandag moontlik heeltemal afwesig by lidmate in die bepaling van hulle kerk-wees nie? Is kerk nie maar kerk nie?

4. In historiese perspektief lyk dit dus asof juis die kerkbegrip en kerkbesef vandag baie ver van die Reformasie en van 1859 af te staan gekom het. Dit mag gedeeltelik saamhang met die geestelike ontwikkeling wat Hoekendijk die „vierde mens" genoem het. Dit kan verder toegeskryf word aan faktore soos anti-paternalisme, die tegnokrasie wat die mens vandag na homself laat vra, die eksistensialisme, wat anti-histories ingestel is, die evolusionisme wat die „moderne" verheerlik, die materialisme by die mens, lidmaat, predikant, ouderling en ' $n$ menigte ander eienskappe van ons tyd miskien selfs aan die hele revolusionêre of eksistensiële beginsel van ,change" ter wille van die ,change” en anti-tradisie-genot. Daar moet egter ook sekere remedies van die kerklike kant self gedoen word.

4.1. Dit is noodsaaklik dat die mens van vandag homself lidmaat sal weet van die kerk as Bybelgetroue kerk en nie maar net een van 'n Kollegialistiese-groep of instituut nie. Sy Christen-wees (onsigbare kerk-wees) moet in geïntegreerde verband met die instituut gesien, behandel en verwerklik word. Die kerklike bediening mag 
nie gerig word op die sekondêre nie. Dit moet altyd op die primêre betrokke bly nl., die geloofsrelasie, Christen-wees, innerlik-persoonlike verhoudinge, die vertikalerelasie en dan horisontaal, die mens in sy lidmaat-wees van die liggaam van Christus wat hom ook met ander gelowiges en mense in verband bring. Te veel egter word die klem gelê op kerkgeboue, sale, traktemente, bloot net bydraes vir sending, Bybelverspreiding, „armkas”, diakens ,,barmhartigheidsdiens", - terwyl die mens in die kerk hom weinig en hoegenaamd nie betrokke voel by die sg. barmhartigheidsdienste, sending of wat ook al nie.

4.2. Die hele kerklike benadering in huisbesoek, kerkraadsvergadering, diakonale diens, klassikale en sinodale aktiwiteite, sal baie meer moet uitgaan van 'n dinamiese i.p.v. 'n statiese koninkryksbegrip. Die gelowiges moet weet dat deur hulle kerkwees is hulle betrokke by die stryd van Jesus Christus teen die Antichris op elke terrein. Die kerugma van die evangelie, die koinonia van die geloof en die diakonia van die ,ampte", raak die hele mens en die hele lewe.

Die kerk moet nie terugval op 'n versmalde ,terrein" of „front" nie, maar juis die kerk-wees moet die wortel wees wat aanleiding gee tot Christelike aksie op alle lewensterreine. Waar nodig moet Christelike aksies op grond van die Christen-wees en kerkwees na vore tree - maar nooit moet Christelike aksies (maatskappye, staat, ens.) langs die kerk te staan kom nie.

Hoekendijk (a.w., p. 22 e.v.) het miskien rede om te beweer dat daar 'n ,verzoeking is om de Kerk zelf te zerieus te nemen en haar uit te nodigen zichzelf als gevestigd te beschouwen, het stevige bruggehoof van God in de wereld, zichzelf te zien als beatus possidens die een bezit, dat anderen niet hebben, uitdeelt, tot er een nieuwe groep possidentes wordt gevormd" (p. 23). Daarmee bedoel hy dat evangelisasie stagneer omdat dit ' $n$ uitnodiging word om by 'n bepaalde kerk aan te sluit. Hy meen dat Voetius ook op voetspoor van hierdie Roomse institusionalisme foutiewelik selfs sending as „plantatio ecclesiae” beskou het. Die punt wat hier opgemerk moet word, is dat dit miskien te veel oor die kerk in sy geïnstitueerde vorm gaan - en te min oor die dinamiese heerskappy, die koninkryk van Jesus Christus oor die hele mens en die hele lewe. Die kerugma moet op die wye lewensfront gerig wees. Die koinonia (gemeentelewe) moet werklik kommunikasie wees. Die diakoniai (bedieninge) moet werklik dienslewering wees en nie bloot opgaan in administrering, regering, voorskrifgewing, ens., nie.

4.3. Dit is nodig dat die antitese van die koninkryk van God in die eie tyd duidelik gesien en gestel word. Te veel word die kerkbegrip verlam wanneer daar versigtige bondgenootskappe gesluit word en gesoek word na sg. ,waarheidsmomente" wat aanwesig kan wees in allerlei eietydse rigtings en beweginge. Sonder die antitese van die koninkryk van God teenoor diê van die Antichris in die persoonlike oortuiging, in die kerklike handeling (veral soos dit plaaslik uitwerk en gesien word) en in die aktiwiteite van Christene na buite op hulle lewensterreine, kan geen lewende kerkbesef gedy nie. Ek meen dat dit dokumentêr maklik aangedui sal 
kan word dat die Reformasie by Luther en Calvyn en die stigting van die GKSA in 1859 een gemeenskaplike nood het: die vraag en die toets of iets "naar Gods Woord" was (vgl. my „Doppers in S.A.", p. 183 en verw. 116). Vandag egter sou die ekwivalente vraag eintlik so gevra word: „Wat sê die Gereformeerde Kerk"? Of wat sê „ons dominee"? Hierdie klerikalisme en institusionalisme is die dood van enige ware kerkbesef.

4.4. Teen die ontsettende stroom van institusionalisering sal wal gegooi moet word. Te veel „,afstigtings" - net om aan „elke dominee sy eie gemeente te gee", d.w.s. afstigting ter wille van die organisasie en gepaardgaande kostes aan geboue, administratiewe uitgawes ens., - begin die mens van vandag vervreem. Handelinge op grond van klassisresepte (al is dit traktering), visitasievoorskrifte of met 'n beroep op sinodebesluite, terwyl daar in die plaaslike kerk-wees weinig oortuiging voor bestaan, vernietig die plaaslike, veroorsaak 'n verlamming en tegelyk 'n geleidelike breuk en vervreemding. Die funksionele organisasie wat dikwels van die kant van vergaderings en selfs ,ampsdraers” gesoek word, spreek die lidmaat nie aan nie. In die dor geestelike lewe van die twintigste eeu soek die gelowige na 'n funksionaliteit in terme van die Skrifbeelde van suurdeeg, sout en lewe - hy weet wat hy wil en laat hom nie voorsê nie.

4.5. In 'n eeu wat gekenmerk word deur sy anti-paternalisme sal 'n baie duidelike gesagsbegrip na vore moet tree. Te veel is daar in die verlede in kerkregering 'n beroep gedoen op die gesag van ampte, predikante, kerkrade, klassisse of sinodes. Die enigste gesag is die van Christus in sy Kerk. Wanneer die bediening - huisbesoek, kategese, prediking, vermaning, ens., 'n duidelike beroep op Christus doen, sal dit ook duidelik wees dat daar geen dualisme bestaan tussen kerk en die Koning van die Kerk nie.

4.6. Met oop oё sal gewaak moet word teen die gevare van formalisering. In baie opsigte beskou lidmate vandag die konfessie, die prediking, kerkbesoek, kategese, belydenis van die geloof, die huweliksluiting, die dienste van ouderling of diaken, as blote formaliteite. Die diens van die dominee word beskou as een van die vele „professionele" dienste in die samelewing wat verrig word op grond van sy B.A. en Th.B. akademiese studie, sy beroepsvorming en nie meer op grond van die roeping wat tot hom gekom het nie.

Die wyse waarop die sg. tweede erediens gemotiveer word soms selfs ' $n$ halfuur na die oggenddiens - wek die indruk dat dit gaan om dooie vorme van twee eredienste, sonder meer. Die idee dat alles wat ,kerklik" is deur die kerkraad geïnisieer of gekommissioneer moet word, maak die ruimte vir individuele inisiatief, belewing en optrede bykans onmoontlik. Die reglementering van kerklike handelinge op huisbesoek, vergaderinge, die swye wat op andersdenkendes ter vergadering gelê word, die onverdraagsaamheid by voorsitters teenoor diegene wat van hulle standpunte verskil, ens., maak die kerk al meer 'n stagnante entiteit wat Hoekendijk noem „een onbeweeglijke structuur" (p. 13). Dit is 'n feit dat sommige gelowiges juis daarom tot kerkbedanking, sektariese rigtings en soos Hoekendijk selfs tot nivellering van die institutêre karakter van 
die kerk as vergadering van gelowiges gebring word.

4.7. Die kerk moet volgens herhaalde roepe van Christus waak teen verwêreldliking. Veral in ons tyd wat duidelik eskatologiese trekke openbaar, moet uiters versigtig omgegaan word met enige kompromis met die wêreld. Derhalwe moet selfs gewaak word teen die klein jakkalsies, hoe effektief hulle soms ook al in die praktyk mag wees, om misstande uit die weg te ruim. Hier dink 'n mens aan sake soos traktementsaanduidinge met skemas wat ontleen is aan die sekulêre wêreld. Waarom moet 'n dominee se versorging eintlik geregtelik bestuur word met soveel en soveel begrotingsposte: biblioteek, vakansiebonus, ens., ens.? Daarby rus vir my nog altyd die vraag of die hele begrip, ,vakansiebonus" rymbaar is met Bybelse beginsels soos, ,die arbeider is sy loon waardig" (waardeur geen loon teruggehou kan word nie) en ook die Skrifbeginsel dat loon en arbeid aan mekaar verbind is - en nie die moderne sosialistiese idee dat arbeid reg gee op eise nie. Daar is talle voorbeelde waar kerklike sake, optrede teenoor lidmate, geregverdig word met beroepe op sekulêre werkpatrone. Vergelykings met sekulêre verenigings, optredes, salarisskale, ens., moet geleidelik die lidmaat onder die indruk bring dat die kerklike instituut maar een van die wêreld se tallose verenigings is. Verandering in wêreldse verenigings is dan ook genoegsaam om ' $n$ appèl tot verandering in dieselfde rigting na die kerk te laat kom.

4.8. Die gelowiges sal met jaloersheid moet veg dat die kerk nie onder allerlei filosofiese en selfs vroom argumente van die lewe geïsoleer word nie. Hoe sentraal die erediens en kerkraad ook mag wees, mag kerk-wees nie opgaan in hierdie twee komponente nie. In die kerklike lewe sal weer met die werklike lcwe van die mens in die kerk geworstel moet word in die lig van God se Woord en die eise van Jesus Christus - dan moet hy inderdaad kerk-wees om kerk te bly.

4.9. Dit is duidelik dat indien die gevaar van institusionalisering ook die kerklike lewe binne die verband van die GKSA bedreig, moet noodwendig die probleem van burokratisering, klerikalisme, predikant-spesialisasie, professorale-spesialisasie, ens., noodwendig onder die oog gesien word. Indien daar in seggingskrag en aansien hiërargië begin ontwikkel op grond van die "status" wat mense beklee, op grond van hulle geleerdheid, ,teologie”, funksie, ampte, ens., - is die skrif van stagnasie ook reeds aan die muur. Allerlei kwaksalwery met die beginsels van die pragmatisme (soos bv. kompensasie deur vroue tot die ampte toe te laat) spruit per slot van sake reeds uit 'n gestagneerde kerklike lewe. Dit is ' $n$ poging om aan vroue op hierdie laaste front - nl. die ampswerk — 'n geleentheid vir lewe te gee omdat die amp van die gelowige verdor het en die vroue nie voel dat hulle kerk-kan-wees in hulle christenwees nie. Wanneer Art. 27 K.O. maar een maal in 'n kerk toegepas was om eintlik die predikant se posisie, of denkwyse of skemas te bevorder, het daardie betrokke kerk 'n skok ontvang waarvan hy miskien nooit self sal kan herstel nie. Hierdie verskynsels bring Hoekendijk so ver om te sê dat die ,beroeps-kerk-mens" (p. 63) 
geen orgaan meer vir die ,apostolaat" kan wees nie. Om die evangelie enigsins vandag nog te laat uitgaan wil hy reeds 'n kompromis maak met die antipatie teen hierdie ,kerklijke label".

'n Mens moet Hoekendijk se antipatie teen die instituut en die ampte veroordeel, maar nie te min moet ' $n$ mens toegee, soos in die historiese oorsig geblyk het, dat vele reformatoriese kerke in hulle ampshiërargie gestagneer het. Wanneer die „orgaan" nie meer geintegreer is met die evangelie nie, verloor hy daarmee sy aktualiteit. In eie kerklike lewe sal teen die stagnering deur spesialisasie gewaak moet word teen kommissies, deputate, adviseurs, professore ens. Die mondigheid van die kerk om met die Woord van God in die hand te handel sonder "n kommissie, adviseur of 'n professor, sal weer sterk na vore moet tree. Dit is alleen in die mondigheid van die amp van die gelowige wat ' $n$ Bybelse kerkbegrip kan wortel. Ek voel tog dat te veel die ,teologie" (die interpretasie, argument en opinie), die produk van menslike wetenskap, na vore tree o.a. kerkregering en belydenis - al sou ek die laaste wees om „teologie" sy bestaansreg te ontsê.

P. J. Huizer (Het verwordingsprocess in de Geref. Kerken, p. 15) skryf die probleme in die GKN toe aan „outoritêre" metodes. Hy definieer outoritarisme as die houding van iemand wat losweg allerlei beweringe doen sonder dat hy enige bewys vir die juistheid daarvan het, maar aanspraak doen dat dit aangeneem moet word omdat dit hy is wat dit sê: „Hy opereert met kreten i.p.v. met argumenten". Daar loop ongetwyfeld bloedspore deur gemeentes wanneer met outoritêre optredes en domino-krasie standpunte oor politiek, modes, universiteitskeuses, dans, kaartspel, bydraes, kerkbesoek, ens., uitsprake gemaak is wat hierdie karakter vertoon het.

4.10. Modernisering en anti-tradisie houding is ook steeds 'n groot gevaar vir kerkbesef. Die naam gereformeerd of hervormed dui telkens op 'n teruggrype. Die Bybelse geskiedbeskouing werk reglynig van skepping na voleinding. Die heidense en Griekse beskouing is egter siklies. Daardeur het gister en môre weinig verband. In ons tyd word alle aandag saamgetrek op die moment van die hede. So ontstaan die gevaar dat as gevolg van gebreke wat in die hede gevind word 'n breuk met die verlede geslaan word en daardeur 'n totale verbandlose kerk-wees en menswees gekweek word wat slegs met die ,moderne", die bytydse in pas wil bly.

Die verheerliking van die afgod ,verandering" en die gees van eksperimentalisme met die liturgie, die bedieninge, prediking, pastoraat, ens., sal geen werklike kerkbesef bring nie. Kerkbesef het te doen met insien, verstaan, verbandligging, ens. Dit vereis die integrasie van begrippe op 'n hoë vlak - en geen onseker geploeter nie. Dit is werklik in ons tyd nie net Kuitert en Wiersinga en andere se Skrifbeskouing wat kerkbesef wil moderniseer nie. Ons moet aanneem dat die tegnokrasie en die sg. „wetenskaplike beskouing”" op sterkte van "teologie" ook onder mense lewe. Met 'n kompromis „modernisering", sal weinig bereik word. Wat nodig is, is 'n simpa- 
tieke benadering waarin die waarheid uit die Skrif teenoor verwarring geponeer word.

4.11. Per slot van sake hang die kerkbesef onlosmaaklik saam met die prediking, wat in 'n sekere sin die sentrum van die gelowige menswees moet bly. Dit is immers in die prediking wat die Woord van die Koning die duidelikste tot Sy volk moet kom. Aangesien dit dus gaan om die Woord van die Koning moet gewaak word teen tradisionele, mooi, kunsmatige, stereotipe, gemaakte, en ander vorme van prediking.

Hoekendijk kritiseer (p. 27) die prediking en sê dat die evangelie in baie opsigte gereduseer word tot ,een par vage religieuse algemeenheden... Trouw aan het Evangelie is iets heel anders dan starheid, in welke vorm ook". Prediking gelaai met gemeenplase, generalisasie, apodiktiese sienswyses van die dominee, outoritarisme, stylblomme, na-apery van ander, onegtheid, ens., moet eenvoudig lei tot 'n verlies van belangstelling in wat die kerk-wees bied.

'n Mens kan Hoekendijk se eensydige nadruk op inhoud met verwerping van die vorm (institusionele) afkeur, maar sou baie gereformeerdes nie ook vandag saam met hom sê ,we moeten opnieuw ontdekken wat de Bijbel onder evangelieverkondiging verstaat" (p. 11). Kerk en evangelie moet geïntegreer wees. Dit moet nie moontlik wees om soos Hoekendijk (p. 12) te beweer dat die evangelie weer gebiede moet bereik wat die kerk verloor het nie.

Die blikrigting van die kerk moet nie gerig wees op ekumenisme en ander institusionele patrone wat in die twintigste eeu pas nie, maar op die amp van die gelowige, die integrasie van die mens se lewe onder die evangelie van Christus Jesus. Kerkbesef bloei en kerkbesef lok en kerkbesef dring in en dring deur wanneer die gelowiges persoonlik en gesamentlik kerk wil wees soos in die tyd van die apostels en apostoliese vaders. Dan is dit 'n leër waarmee Christus Jesus wêreldryke (Rooms Romeinse Ryk) verower.

B. Spoelstra.

(Na aanleiding van ' $n$ voordrag voor die G.T.V. Pretoria in 1973) 